\title{
Changes in the Activity and Gene Expression of Sorbitol- and Sucrose-related Enzymes Associated with Development of 'La France' Pear Fruit
}

\author{
Kunio Yamada ${ }^{1}$, Yasufumi Suzue ${ }^{1}$, Saori Hatano ${ }^{1}$, Miwa Tsukuda ${ }^{1}$, Yoshinori Kanayama², \\ Katsuhiro Shiratake ${ }^{1}$ and Shohei Yamaki ${ }^{1 *}$ \\ ${ }^{1}$ Graduate School of Bioagricultural Sciences, Nagoya University, Chikusa-ku, Nagoya 464-8601, Japan \\ ${ }^{2}$ Graduate School of Agricultural Sciences, Tohoku University, Tsutsumidori, Amamiyamachi, Aoba-ku, Sendai 981-8555, Japan
}

\begin{abstract}
To clarify the roles of the five sorbitol- and sucrose-related enzymes important to the development of ' $\mathrm{La}$ France' pear fruit, we traced the fluctuations in the activities and mRNA levels of these enzymes. Such an approach of simultaneously assaying five sugar-metabolizing enzymes is a first in pear fruit and the Rosaceae family. Both the activity and the mRNA level of NAD ${ }^{+}$-dependent sorbitol dehydrogenase (NAD-SDH) were high in young fruit, but decreased during fruit enlargement and rose again with fruit maturation. Sucrose synthase (SS) showed nearly the same fluctuation pattern as did NAD-SDH. The changes in both NAD-SDH and SS activities, based on fresh weight, were proportional to that of the relative growth rate (RGR) of the fruit. This suggests that they function closely in supplying hexose from the unloaded sugars in the phloem for active growth. Two isogenes of soluble acid invertase (S-AIV), $S$-AIV1 and $S$-AIV2, were present in pear fruit; the former was expressed highly in young fruit, whereas the latter was expressed both in young and mature fruits. The fluctuation pattern of the activity for sorbitol-6-phosphate dehydrogenase (S6PDH) was similar to that of NAD-SDH. However, the role of S6PDH in fruit is unclear. Although sucrose phosphate synthase (SPS) activity was higher in young fruit, it decreased and remained low with fruit maturation. This may be attributed to the finding that 'La France' pear fruit accumulates hexose but not sucrose. These results showed that NAD-SDH, SS, and S-AIV are of prime importance in supplying sugars for the development and accumulation of hexose necessary for pear fruit enlargement.
\end{abstract}

Key Words: gene expression, Pyrus communis, sink and source functions, sorbitol-related enzymes, sucrose-related enzymes.

\section{Introduction}

The sugar content in fruit and the enhancement of fruit development are mainly dependent on the metabolism of unloaded sugars in the phloem and the accumulation of their metabolites. Pear (Pyrus communis L. var. sativa DC. 'La France') fruit belongs to the Rosaceae family, in which the translocating sugars are sorbitol and sucrose. Therefore, we investigated the changes in the activity and gene expression of sorbitol- and sucrose-related enzymes during the development of pear fruit.

As for sorbitol metabolism, the sugar alcohol that is translocated into the fruit (sink tissue) is converted to fructose by NAD-SDH. The expression of NAD-SDH paralleled the accumulation of fructose, so that its activity suggested a transcriptional regulation in the apple fruit (Yamada et al., 1999), peach fruit (Yamada et al., 2001), and loquat fruit (Bantog et al., 2000).

Received; June 21, 2004. Accepted; July 29, 2005.

This research was supported in part by grants-in-aid (No. 09306002) from the Ministry of Education, Science, Sports and Culture of Japan. * Corresponding author (E-mail: yamaki@agr.nagoya-u.ac.jp).
S6PDH, which synthesizes sorbitol in leaf, was reported to be present in Japanese pear fruit (Yamaki and Moriguchi, 1988). However, its expression on the gene level was not investigated, so that its role in fruit development remains ambiguous.

In sucrose metabolism, the rise of SS and SPS activities rather than the decrease in S-AIV activity was related to the accumulation of sucrose with maturation of Japanese pear fruit (Moriguchi et al., 1992). In particular, two isozymes of SS are present in fruit, one increases with fruit maturation and contributes to sucrose accumulation (Tanase and Yamaki, 2000). SS was shown to contribute to the unloading of sucrose into tomato fruit, because antisense inhibition of SS decreased the unloading of sucrose to young fruit (D'Aoust et al., 1999). Furthermore, the over-expression of SPS was reported to enhance sucrose unloading in transgenic tomato fruit (Nguyen-Quoc et al., 1999). S-AIV is also associated with the control of the ratio of hexose to sucrose, which influences fruit size through osmotic pressure (Klann et al., 1996). Two isogenes of vacuolarAIV were found in grapes, one is expressed with fruit maturation and participates in the accumulation of hexose (Davies and Robinson, 1996). Two isozymes of 
S-AIV from Japanese pear fruit have been purified and characterized (Hashizume et al., 2003).

Consequently, the above five enzymes play prime roles in sugar accumulation and development of fruit. However, their gene expression has not been reported so that no studies on the comparison of gene expression between sorbitol- and sucrose-related enzymes have been made in Rosaceae fruit. The purpose of this study was to investigate simultaneously the activities of the five enzymes and their mRNA levels in relation to sorbitol and sucrose metabolism in the developing pear fruit.

\section{Materials and Methods}

\section{Plant Materials}

Ten to 20 fruits were harvested throughout the 2001 season from a 15-year-old pear tree, (Pyrus communis L. var. sativa DC. 'La France') grown in the orchard of Nagoya University. Fruit development stages were recorded as days after full bloom (DAF). The date of full bloom was April 5, 2001. A portion of each fruit was diced into small pieces, placed immediately in liquid nitrogen, and stored at $-80^{\circ} \mathrm{C}$ until used. All assays of the enzyme activities and mRNA levels were carried out in triplicate.

\section{Total RNA extraction and northern blot analysis}

The extraction of total RNA and blotting were described in the method of Bantog et al. (2000). For hybridization, the probes for mRNAs were labeled by random primer incorporation of dUTP, linked to digoxigenin (DIG) by using the DIG-labeling Kit (Roche Diagnostics Co., IND, USA). The hybridization was carried out at $68^{\circ} \mathrm{C}$ in $5 \times \mathrm{SSC}(750 \mathrm{mM} \mathrm{NaCl}, 75 \mathrm{mM}$ sodium citrate) that contained $1 \%(\mathrm{w} / \mathrm{v})$ blocking reagent (Roche Diagnostics Co.), 0.1\% (w/v) lauroylsarcosine, and $0.02 \%(\mathrm{w} / \mathrm{v})$ SDS. The blotted membranes were washed in $2 \times \mathrm{SSC}$ that contained $0.1 \%(\mathrm{w} / \mathrm{v})$ SDS for $5 \mathrm{~min}$ at $25^{\circ} \mathrm{C}$ twice and $0.1 \times \mathrm{SSC}$ that contained $0.1 \%$ $(\mathrm{w} / \mathrm{v}) \mathrm{SDS}$ for $15 \mathrm{~min}$ at $68^{\circ} \mathrm{C}$ twice. The hybridization was detected immunologically with alkaline phosphatase that was conjugated to antibodies against DIG and CDPstar (Tropix Inc., Bedford, MA, USA). Chemiluminescence was recorded on X-ray films.

\section{Preparation of probes}

cDNA fragments of pear NAD-SDH, S6PDH, SPS, SS, and S-AIV were amplified by RT-PCR. From the total RNAs that were prepared from mature leaves on July 7 for SPS, S6PDH, and SS or from mature fruit on September 13 for NAD-SDH and S-AIV, the first strand cDNA was synthesized by using an oligo dT-adaptor primer as recommended in the TaKaRa RNA PCR Kit (AMV) ver. 2.1 (TaKaRa Biomedicals, Shiga, Japan). Two oligonucleotide primers for each cDNA were designed as follows: For S6PDH, sense primer: 5'TGGTGGAGGCCTGTAAGAAC-3', antisense primer: 5'-AGCTGTGGGAAGAACGCCGTG-3'; for NAD-
SDH, sense primer: 5'-TGGTCGTGGGAGCAGGACCTATA-3', antisense primer: 5'-GTGAAGCCCCTCATAACACATCGG-3'; for SPS, sense primer: 5'GATTCTGATACTGCTGGTCAGGT-3', antisense primer: 5'-CTGCTTGTGGTGTTTAGGATAAGC-3'; for SS, sense primer: 5'-AT(G/A)TG(G/A/T/C)GT(G/A)TG(T/C) $\mathrm{AC}(\mathrm{G} / \mathrm{A} / \mathrm{T} / \mathrm{C}) \mathrm{CC}-3^{\prime}$, antisense primer: 5 '- $\mathrm{CC}(\mathrm{G} / \mathrm{A} / \mathrm{T} /$ C)GG(G/A/T/C)GT(G/A/T/C)TGGGA(T/C)TA(T/C)GT3'; for S-AIV, sense primer: 5'-TGGCAA(A/C)G(A/ C)AC(G/T)GC(G/T)T(A/T)(T/C)CAT-3', antisense primer: 5'-GTA(G/A)AA(G/A)TCCAC(G/A)CACTCCCACAT3'. Each PCR was performed with both primers by using the first strand cDNA described above as the template. An amplified fragment was cloned into a pT7BlueTvector (Novagen, Madison, WI, USA) by the TA cloning method (Ichihara and Kurosawa, 1993) and sequenced by an ABI PRISM Big Dye Terminator Cycle Sequencing Ready Reaction Kit (Perkin-Elmer, Foster City, CA, USA) by using an automatic DNA sequencer (Model 373, Perkin-Elmer). In using this plasmid DNA as template, PCR was performed with the same primers. An amplified fragment was used as a probe in northern blot analysis. The cDNA fragments of S6PDH, NADSDH, SPS, SS, and S-AIV comprised 370, 441, 1098, 813 , and $600 \mathrm{bp}$, respectively. The deduced amino acid sequences of pear S6PDH (DDBJ accession number: AB190795), NAD-SDH (AB190796), SPS (AB190797), and $S S$ (AB190798) revealed about $95 \%$ identity to those of apple, about $90 \%$ identity to those of apple and loquat, about $80 \%$ identity each to those of Citrus unshiu, respectively. The PCR product of S-AIV consisted of two isogenes (S-AIV1 (AB190799) and S-AIV2 (AB190800)). S-AIV1 showed $73.5 \%$ identity to SAIV2, based on amino acid sequence and about $80 \%$ identity to grape, while S-AIV2 revealed about $80 \%$ identity to Arabidopsis.

\section{Enzyme extraction}

S6PDH and NAD-SDH enzymes were extracted by the modification of the method of Yamada et al. (2001). SPS, SS, and S-AIV enzymes were extracted by the modification of the method of Tanase and Yamaki (2000).

\section{Enzyme assay}

S6PDH and NAD-SDH activities were determined spectrophotometrically, following the reduction of $\mathrm{NADP}^{+}$or $\mathrm{NAD}^{+}$at $340 \mathrm{~nm}$, as described by Yamaki and Ishikawa (1986). SPS, SS, and S-AIV activities were assayed by the method of Moriguchi et al. (1992). The glucose produced was assayed by the glucose oxidase method (B-Test Wako Glucose Assay Kit, Wako Pure Chemical Industries Ltd., Osaka, Japan).

\section{Protein extraction and determination}

For the soluble protein assay, extracts of S6PDH and NAD-SDH from fruit were analyzed by the method of 
Yamada et al. (2001).

\section{Determination of relative growth rate}

The relative growth rate (RGR) of fruit was calculated by the following formula: $\mathrm{RGR}=\left(\mathrm{In}_{\mathrm{n}}-\mathrm{In} \mathrm{W}_{\mathrm{n}-1}\right) /$ $\left(T_{n}-T_{n-1}\right)$, where $W$ and $T$ represent the fresh weight and DAF on the sampling dates, respectively.

\section{Results}

\section{Changes in fresh weight and relative growth rate}

The sigmoidal curve of pear fruit growth was revealed that the relative growth rate of fruit was high in young fruit, dropped rapidly with fruit enlargement, and reached a minimum level at $92 \mathrm{DAF}$. Thereafter, it rose slightly, but temporarily in pre-mature fruit (106 and $123 \mathrm{DAF}$ ), and decreased again with maturation (Fig. 1).

\section{Activity and $m R N A$ level of NAD-SDH with fruit develop- ment}

The level of NAD-SDH mRNA was higher in young fruit, declined gradually with the enlargement of fruit, and reached a minimum level at 106 DAF. Thereafter, it regained its high level from 123 to 162 DAF when the fruit matured. The activity of NAD-SDH, based on fresh weight, was clearly high in young fruit (18 and 32 DAF), dropped significantly with fruit enlargement, and increased slightly again with fruit maturation. The fluctuation pattern of activity based on protein content throughout the developmental stages, was approximately proportional to that of the mRNA level (Fig. 2).

\section{Activity and mRNA level of S6PDH with fruit development}

The level of S6PDH mRNA reached its maximum at $150 \mathrm{DAF}$, but it did not show a clear inclination throughout the developmental stages. The activity on a fresh weight basis was also high in young fruit (18 and

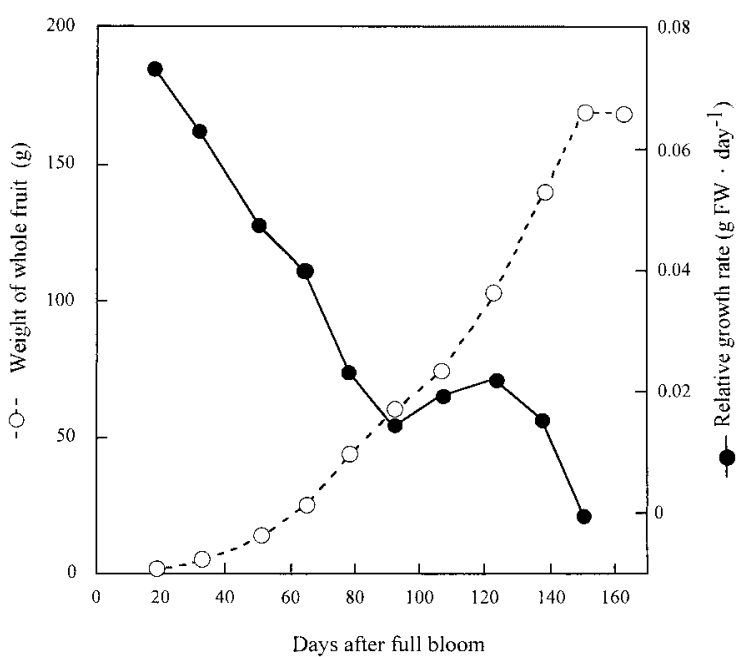

Fig. 1. Seasonal changes in fresh weight (open circle) and the relative growth rate (closed circle) during fruit development of pear. Data points are means of 10 fruits ( 78 to $162 \mathrm{DAF}$ ) and 30 fruits (18 to $64 \mathrm{DAF}) \pm \mathrm{SD}$. All SD bars are smaller than each symbol.
$50 \mathrm{DAF})$, declined with fruit enlargement and rose again with fruit maturation. The growth increment in mature fruit conformed more clearly by the activity based on protein content rather than on fresh weight. However, we could not detect the activity at 32 DAF probably because of the artificial effect (Fig. 3).

\section{Activity and mRNA level of SS with fruit development}

The expression of $S S$ in fruit was similar to that of $N A D-S D H$. The level of SS mRNA was high on 18 and $32 \mathrm{DAF}$, ebbed with fruit enlargement but regained its high level when the fruit matured. The activity of SS on protein content basis paralleled the fluctuation pattern of the mRNA level (Fig. 4).

\section{Activity and $m R N A$ level of SPS with fruit development}

The fluctuation pattern of SPS mRNA, expressed at low level in fruit throughout the development stages, corresponded roughly to that of the SS mRNA level.

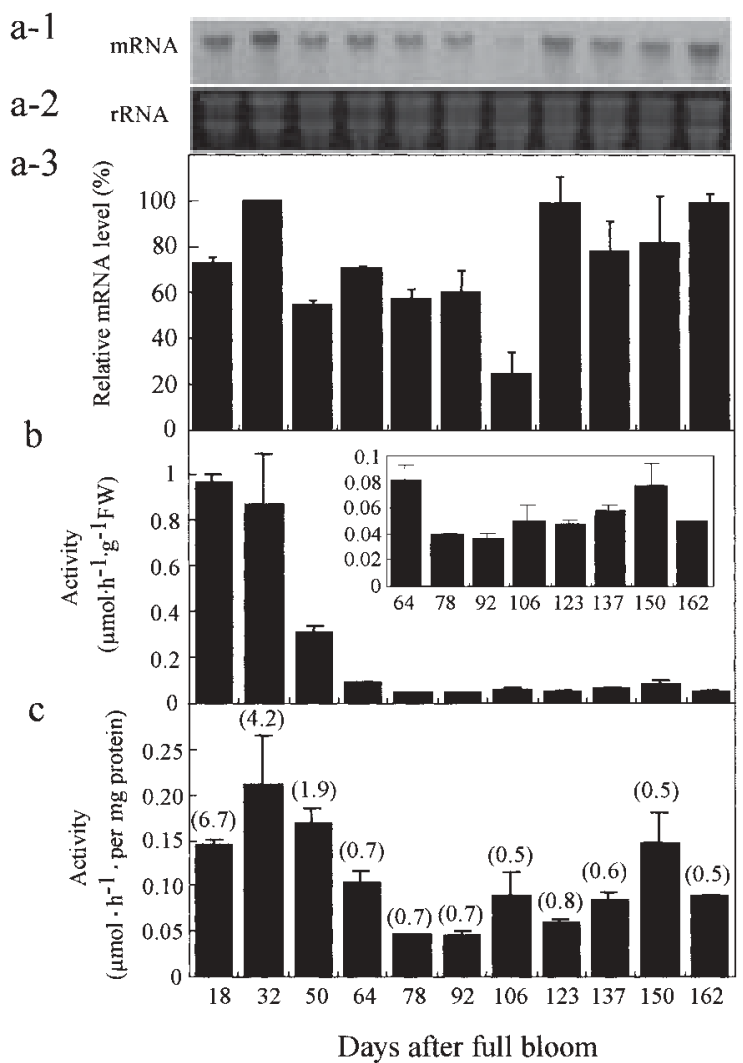

Fig. 2. Changes in NAD-SDH expression in pear fruit flesh at different developmental stages. a-1: The level of NAD-SDH mRNAs, a-2: Ethidium bromide-stained RNA gel as a control for loading, a-3: Relative mRNA accumulation (\% to $32 \mathrm{DAF}$ ) determined by densitometric scanning, $b$ : NAD-SDH activity per $g$ fresh weight, c: NAD-SDH activity per $\mathrm{mg}$ protein. Data points are the means \pm SD of three independent experiments. Total RNA $(15 \mu \mathrm{g} /$ lane) isolated from each sample was hybridized with the DIGlabeled NAD-SDH cDNA probe from pear fruit in a-1. The inset graph in b shows an enlarged profile of the activity from 64 to 162 days after full bloom. The numbers in parenthesis shows the protein contents $\left(\mathrm{mg} \cdot \mathrm{g}^{-1} \mathrm{FW}\right)$. 


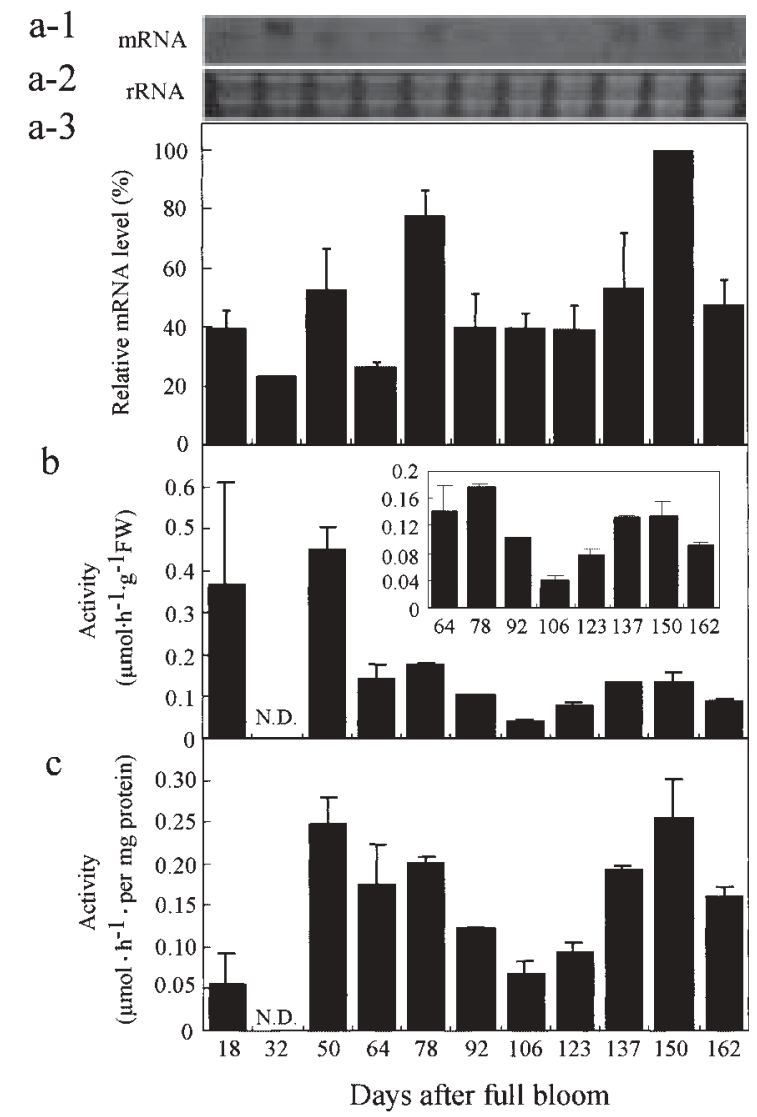

Fig. 3. Changes in S6PDH expression in pear fruit flesh at different developmental stages. Data points are the means \pm SD of three independent experiments. a-1: The level of S6PDH mRNAs, a-2: Ethidium bromide-stained RNA, a-3: Relative mRNA accumulation ( $\%$ to $150 \mathrm{DAF}), \mathrm{b}$ : S6PDH activity per $\mathrm{g}$ fresh weight, $\mathrm{c}$ : S6PDH activity per mg protein. Each band was hybridized with the DIG-labeled S6PDH cDNA probe from pear fruit in a- 1 . The inset graph in $\mathrm{b}$ shows an enlarged profile of the activity from 64 to 162 days after full bloom. N.D.: not detected.

The activity of SPS, based on fresh weight or protein content was high in young fruit, declined rapidly with enlargement, and increased only slightly with fruit maturation, similar to that of the mRNA level (Fig. 5).

\section{Expression of S-AIV with fruit development}

The level of S-AIV1 mRNA was high only in young fruit, dropped rapidly with fruit enlargement and remained low with fruit maturation. On the other hand, the S-AIV2 mRNA was also expressed at a high level in young fruit, dropped with fruit enlargement, as did the S-AIV1 mRNA, but the level increased again as the fruit matured. The activity of S-AIV based on fresh weight, likewise, was high in young fruit, declined rapidly with fruit enlargement, and rose again slightly with fruit maturation. The increment in the maturing fruit was more obvious when based on a protein content (Fig. 6).

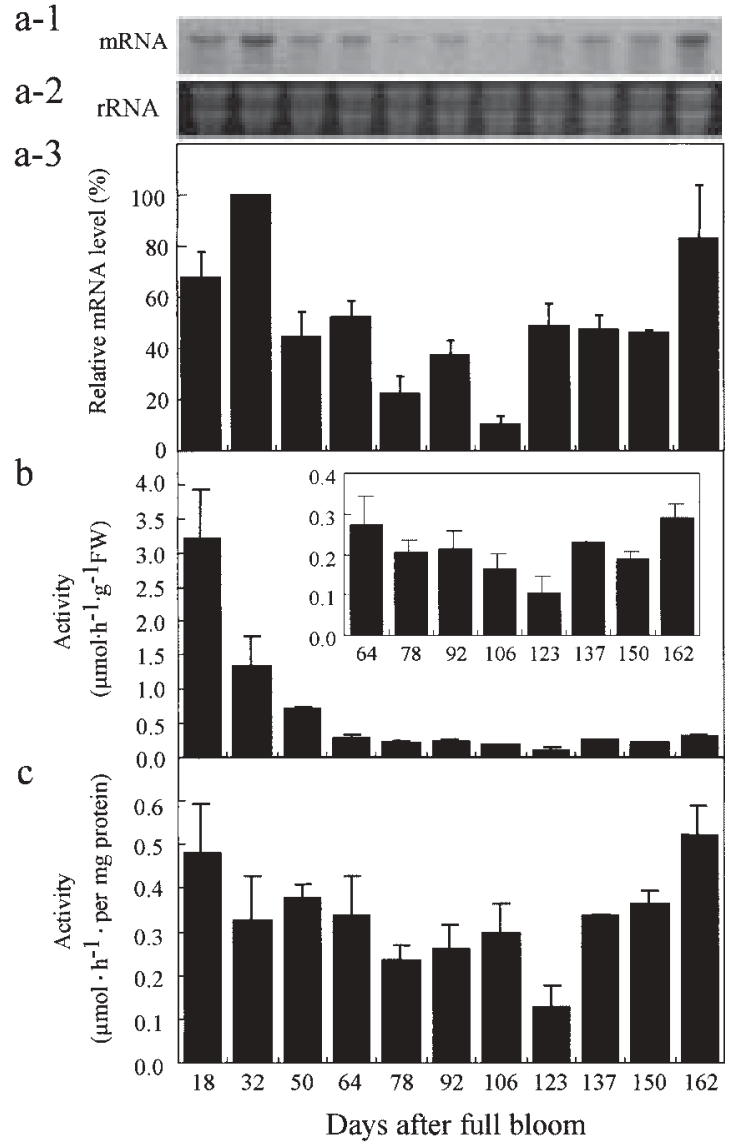

Fig. 4. Changes in SS expression in pear fruit flesh at different developmental stages. a-1: The level of SS mRNAs, a-2: Ethidium bromide-stained RNA, a-3: Relative mRNA accumulation ( $\%$ to 32 DAF), b: SS activity per g fresh weight, c: SS activity per mg protein. Data points are the means \pm SD of three independent experiments. Each band was hybridized with the DIG-labeled SS cDNA probe from pear fruit in a-1. The inset graph in b shows an enlarged profile of the activity from 64 to 162 days after full bloom.

\section{Discussion}

The changes in NAD-SDH activity, based on fresh weight of pear fruit, were proportionate to those in RGR. The changes in activity, based on protein content, corresponded to those in the transcript level, as in other Rosaceae fruits (Yamada et al., 1999, 2001). Thus, it is considered that NAD-SDH in pear fruit plays an important role in sorbitol metabolism during the fruit enlargement phase. NAD-SDH in apple was reported to belong to a multigene family (Nosarszewski et al., 2004; Park et al., 2002). We detected one band in the northern blot analysis by using the probe designed based on the coding region of the cDNA fragment. However, from our results, it is difficult to say whether pear fruits have isogenes. The changes in S6PDH activity were similar to those in NAD-SDH. However, the fluctuation pattern of its activity did not correspond to that of the transcripts. Based on our results, it is difficult to explain this discrepancy. We need to verify the presence of $N A D$ - 


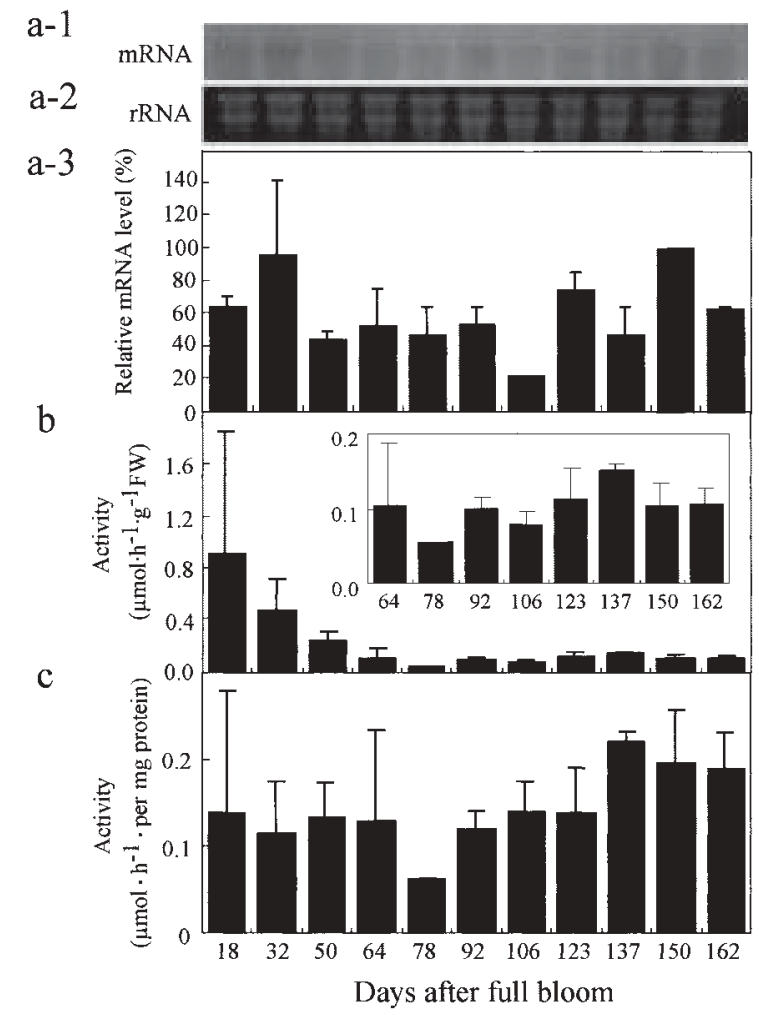

Fig. 5. Changes in SPS expression on pear fruit flesh at different developmental stages. a-1: The level of SPS mRNAs, a-2: Ethidium bromide-stained RNA, a-3: Relative mRNA accumulation (\% to 32 DAF), b: SPS activity per $g$ fresh weight, c: SPS activity per $\mathrm{mg}$ protein. Data points are the means \pm SD of three independent experiments. Each band was hybridized with the DIG-labeled SPS cDNA probe from pear fruit in $\mathrm{a}-1$. The inset graph in $\mathrm{b}$ shows an enlarged profile of the activity from 64 to 162 days after full bloom.

$S D H$ and $S 6 P D H$ isogenes by using other stages of pear fruit, and to analyze their expressions. Until then, we will not be able to clarify their gene expressions separately during fruit development. The role of S6PDH in pear fruit is not clear. The activity of S6PDH in mature fruit remained higher than that of NAD-SDH, as in the loquat fruit (Bantog et al., 2000). S6PDH seems to contribute to sorbitol synthesis in the fruit itself, although hexoses were never converted to sorbitol in fruit (Hansen and Ryugo, 1979). Consequently, it will be necessary to investigate the existence of a system with S6PDH synthesizing sorbitol in fruit itself.

The fluctuation patterns of the expression of SS mRNA and the activity based on protein content were nearly the same. The trends in activity, based on fresh weight, were similar to those in the RGR; they suggest that SS plays an important role for sucrose metabolism during fruit enlargement as does NAD-SDH for sorbitol metabolism. It was reported that SS has two isoforms (SS I and SS II) in Japanese pear fruit. The role of SS I was the degradation of translocated sucrose in young fruit whereas SS II was the synthesis of sucrose in mature fruit (Tanase and Yamaki, 2000). Our present result

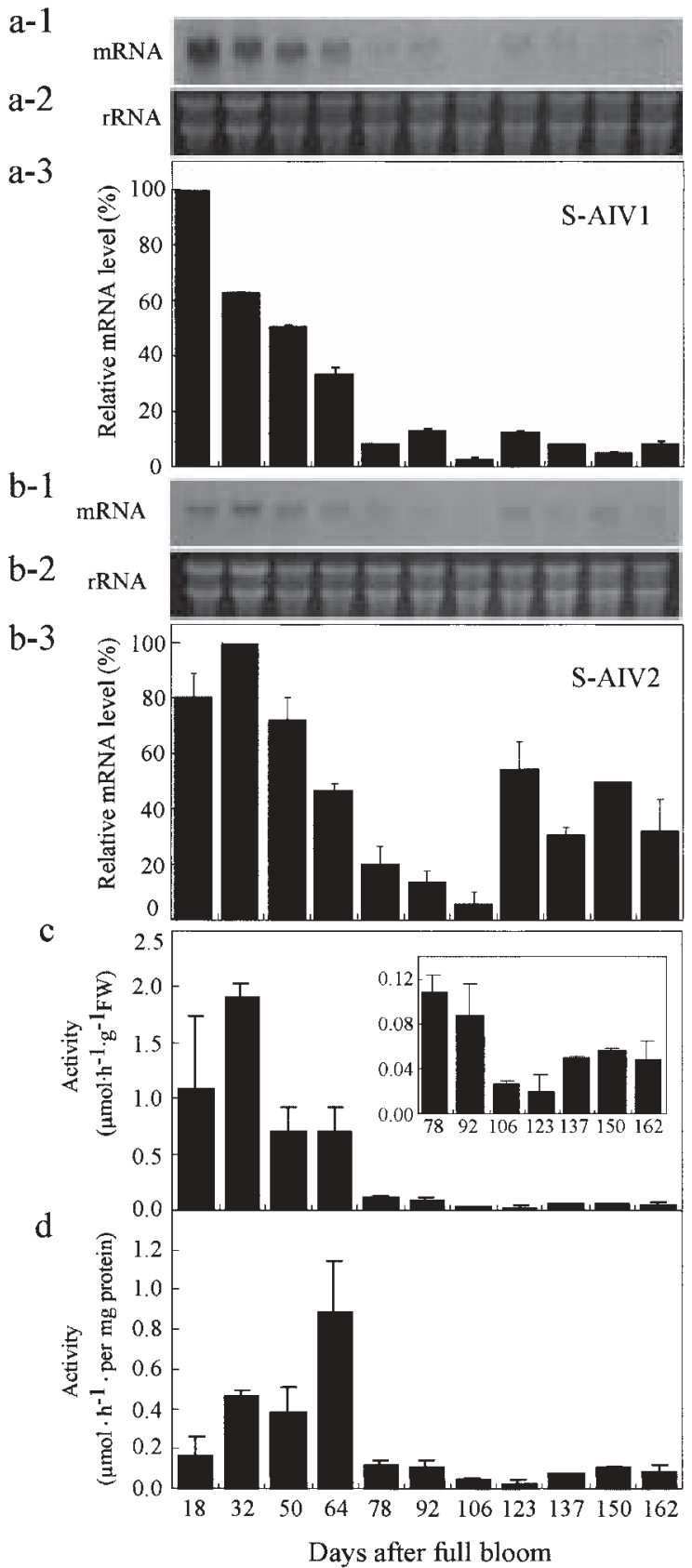

Fig. 6. Changes in $S$ - $A I V$ expression in pear fruit flesh at different developmental stages. a-1: The level of S-AIV1 mRNAs, a-2: Ethidium bromide-stained RNA, a-3: Relative mRNA accumulation (\% to 18 DAF) of S-AIV1, b-1: The level of S-AIV2 mRNAs, b-2: Ethidium bromide-stained RNA, b-3: Relative mRNA accumulation (\% to 32 DAF) of S-AIV2, c: S-AIV activity per $g$ fresh weight, d: S-AIV activity per mg protein. Data points are the means \pm SD of three independent experiments. Each band was hybridized with the DIG-labeled $S$-AIVI cDNA probe from pear fruit in a-1. The inset graph in c shows an enlarged profile of the activity from 78 to 162 days after full bloom.

revealed a slight increase in SS activity in 'La France' pear of the hexose-accumulating type. However, SS activity increased clearly in the sucrose-accumulating type of other pear fruit (Moriguchi et al., 1992). Although there is a possibility that pear fruit has $S S$ isogenes, we 
detected only one band in the northern blot analysis by using the probe designed based on the coding region of the cDNA fragment. We need to find out if there are $S S$ isogenes by using other stages or tissue samples, and to seek their expression. The $S S$ isoforms and the direction of the SS enzyme reaction in vivo are important research areas in the future. The changes in SPS transcript level were in proportion to those of the activity based on protein content, but the activity increased only slightly with fruit maturation. However, sucrose production in mature fruit $\left(0.2 \mu \mathrm{mol} \cdot \mathrm{h}^{-1} \cdot \mathrm{g}^{-1} \mathrm{FW}\right)$ was very low, compared with the production in mature fruit of Japanese pear that accumulate sucrose ( 2 to $6 \mu \mathrm{mol} \cdot \mathrm{h}^{-1} \cdot \mathrm{g}^{-1} \mathrm{FW}$ ). Since 'La France' mature fruit accumulates mainly fructose (about 50\%), sorbitol (about 30\%), and sucrose (about 5\%), it seems that it is a hexose-accumulating type (unpublished data) which may explain the low SPS activity.

The probes for S-AIV1 mRNA and S-AIV2 mRNA did not cross-react with each other since the expression of S-AIV1 mRNA differed clearly from that of S-AIV2 mRNA in the leaf. S-AIV1 mRNA is expressed not only in leaf and fruit, but also in shoot apex, stem, and root, whereas S-AIV2 mRNA is expressed only in sink tissues of fruit, shoot apex, and root (data not shown). The levels of S-AIV1 and S-AIV2 mRNAs in pear fruit were high in young fruit and dropped with fruit enlargement. However, S-AIV2 mRNA increased again with fruit maturation. Thus, the supply of hexose in the vacuoles of young fruit seems to be caused by the expression of both $S$-AIV1 and $S$-AIV2 genes, the accumulation of hexose with fruit maturation may be an expression of the $S$-AIV2 gene. In grapes that accumulate much hexose, the levels of activity and transcript of S-AIV increased before veraison, at which the fruit started to accumulate hexose (Davies and Robinson, 1996). Therefore, it would be very interesting to investigate whether the $S$-AIV2 gene is expressed or not in other hexose-accumulating fruit.

It is unclear yet whether the pathway in unloading of translocated sugars in pear fruit is symplastic or apoplastic. In the case of a symplastic pathway, sorbitol and sucrose are converted to their respective metabolites by NAD-SDH, and SS and neutral invertase, respectively. On the other hand, in the apoplastic pathway, cell wall (apoplastic) AIV will participate. In this experiment, both neutral invertase and apoplastic AIV activities were significantly lower than S-AIV (data not shown) and negligible, compared with the activities of SS and NADSDH. Thus, NAD-SDH and SS are mainly the enzymes involved in the unloading of sorbitol and sucrose in pear fruit. SS activity remained higher than that of NADSDH throughout the developmental stages, and contributed 60 to $85 \%$ of the sum of both activities (data not shown). This could mean that sucrose is more readily available as the main translocating sugar than sorbitol. However, the maximum activities of both enzymes in vitro may not necessarily reflect the activities of both enzymes in vivo since they are regulated by many factors in vivo. The translocating sugars in peach were composed of sorbitol (about 80\%) and sucrose (about $20 \%$ ) (Moing et al., 1997). Similarly, the phloem exudate from the peduncle of apple fruit was composed about $70 \%$ sorbitol and about 30\% sucrose (Klages et al., 2001). The activities of NAD-SDH and SS functioning simultaneously to unload sorbitol and sucrose correlated with the enlargement of fruit as indicated by the RGR (Opara, 2000). Sorbitol and sucrose unloaded in the fruit are actively converted to hexose by NAD-SDH and SS, respectively, whose activities are mainly regulated by their gene expression in fruit development. Thus, the fruit accumulates hexose, sucrose and sorbitol in the vacuoles; the sucrose in vacuole is then converted to hexose by S-AIV. Consequently, the osmotic pressure in the vacuole increased, resulting in an increase in tugor, which, in turn, leads to the enlargement and growth of the fruit.

\section{Acknowledgement}

The authors thank Mr. K. Sakakibara for his assistance in culturing the pear tree.

\section{Literature Cited}

Bantog, N. A., K. Yamada, N. Niwa, K. Shiratake and S. Yamaki. 2000. Gene expression of $\mathrm{NAD}^{+}$-dependent sorbitol dehydrogenase and $\mathrm{NADP}^{+}$-dependent sorbitol6-phosphate dehydrogenase during development of loquat (Eriobotrya japonica Lindl.) fruit. J. Japan. Soc. Hort. Sci. 69: 231-236.

D'Aoust, M.-A., S. Yelle and B. Nguyen-Quoc. 1999. Antisense inhibition of tomato fruit sucrose synthase decreases fruit setting and the sucrose unloading capacity of young fruit. Plant Cell 11: 2407-2418.

Davies, C. and S. P. Robinson. 1996. Sugar accumulation in grape berries. Plant Physiol. 111: 275-283.

Hansen, P. and K. Ryugo. 1979. Translocation and metabolism of carbohydrate fraction of ${ }^{14} \mathrm{C}$-photosynthates in 'French' prune, Prunus domestica L. J. Amer. Soc. Hort. Sci. 104: 622-625.

Hashizume, H., K. Tanase, K. Shiratake, H. Mori and S. Yamaki. 2003. Purification and characterization of two soluble acid invertase isozymes from Japanese pear fruit. Phytochemistry 63: 125-129.

Ichihara, Y. and Y. Kurosawa. 1993. Construction of new T vectors for direct cloning of PCR products. Gene 130: $153-154$.

Klages, K., H. Donnison, J. Wunsche and H. Boldingh. 2001. Diurnal changes in non-structural carbohydrates in leaves, phloem exudates and fruit in 'Braeburn' apple. Aust. J. Plant Physiol. 28: 131-139.

Klann, E. M., B. Hall and A. B. Bennett. 1996. Antisense acid invertase (TIV1) gene alters soluble sugar composition and size in transgenic tomato fruit. Plant Physiol. 112: $1321-1330$. 
Moing, A., F. Carbonne, B. Zipperlin, L. Svanell and J. P. Gaudiliere. 1997. Phloem loading in peach: Symplastic or apoplastic? Physiol. Plant. 101: 489-496.

Moriguchi, T., K. Abe, T. Sanada and S. Yamaki. 1992. Levels and role of sucrose synthase, sucrose-phosphate synthase and acid invertase in sucrose accumulation in fruit of Asian pear. J. Amer. Soc. Hort. Sci. 117: 274-278.

Nguyen-Quoc, B., H. N'tchobo, C. H. Foyer and S. Yelle. 1999. Overexpression of sucrose phosphate synthase increases sucrose unloading in transformed tomato fruit. J. Exp. Bot. 50: 785-791.

Nosarszewski, M., A. M. Clements, A. B. Downie and D. D. Archbold. 2004. Sorbitol dehydrogenase expression and activity during apple fruit set and early development. Physiol. Plant. 121: 391-398.

Opara, L. U. 2000. Fruit growth measurement and analysis. Hort. Rev. 24: 373-432.

Park, S. W., K. J. Song, Y. M. Kim, J.-H. Hwang, Y. U. Shin, W.-C. Kim and W. Chung. 2002. Molecular cloning and characterization of four cDNAs encoding the isoforms of NAD-dependent sorbitol dehydrogenase from the Fuji apple. Plant Sci. 162: 513-519.
Tanase, K. and S. Yamaki. 2000. Sucrose synthase isozymes related to sucrose accumulation during fruit development of Japanese pear (Pyrus pyrifolia Nakai). J. Japan. Soc. Hort. Sci. 69: 671-676.

Yamada, K., H. Mori and S. Yamaki. 1999. Gene expression of NAD-dependent sorbitol dehydrognease during fruit development of apple (Malus pumila Mill. var. domestica Schneid.). J. Japan. Soc. Hort. Sci. 68: 1099-1103.

Yamada, K., N. Niwa, K. Shiratake and S. Yamaki. 2001. cDNA cloning of NAD-dependent sorbitol dehydrogenase from peach fruit and its expression during fruit development. J. Hort. Sci. Biotech. 76: 581-587.

Yamaki, S. and K. Ishikawa. 1986. Roles of four sorbitol related enzymes and invertase in the seasonal alteration of sugar metabolism in apple tissue. J. Amer. Soc. Hort. Sci. 111: 134-137.

Yamaki, S. and T. Moriguchi. 1988. Seasonal fluctuation of sorbitol-related enzymes and invertase activities accompanying maturation of Japanese pear (Pyrus serotina Rehder var. culta Rehder) fruit. J. Japan. Soc. Hort. Sci. 57: $602-607$.

$$
\begin{gathered}
\text { セイヨウナシ ‘ラ・フランス’ 果実の生長に伴らソルビトールおよびスクロース代謝関連酵素の } \\
\text { 活性と遺伝子発現の変動 } \\
\text { 山田邦夫 }{ }^{1} \text { 鈴江康文 }{ }^{1} \text { 波田野沙織 } 1 \text { ・佃 美和 }{ }^{1} \text { 金山喜則 }{ }^{2} \text { 白武勝裕 } 1 \text { 山木昭平1 } \\
\text { 1名古屋大学大学院生命農学研究科 } \quad 464-8601 \text { 名古屋市千種区不老町 } \\
\text { 2東北大学大学院農学研究科 } 981-8555 \text { 仙台市青葉区堤通雨宮町 }
\end{gathered}
$$

\footnotetext{
セイヨウナシ果実 ‘ラ・フランス’ の生長に関係する 5 種類のソルビトール拈よびスクロース代謝酵素の役割 を明らかにするために，それらの活性と mRNA 発現レ ベルの変動を測定した. $\mathrm{NAD}^{+}$依存性ソルビトール脱水 素酵素（NAD-SDH）の活性と mRNA 発現レベルは幼果 で高く，肥大生長と共に低下し，成熟に伴って再び上昇 した。 スクロース合成酵素（SS）のそれらも NAD-SDH と同様の変動パターンを示し，その活性は転写レベルで 調節されているように思われた. NAD-SDH と SS 活性 の変動は新鮮重当たりの相対生長速度（RGR）の変動に も相応した．このことは両酵素が生長に必要なへキソー スを転流糖より供給することに密接な役割を演じている ことを示唆する. 可溶性酸性インベルターゼ（S-AIV）に
}

は $S$ - $A I V 1$ と $S$ - $A I V 2$ の 2 つの遺伝子が存在した. $S$ - $A I V 1$ は幼果での夕発現し，一方， $S$-AIV2 は幼果と成熟果の両 方で発現した。ソルビトール-6-リン酸脱水素酵素 (S6PDH) の活性変動は NAD-SDH と類似していた。 し かしながら，S6PDH の果実における役割は不明である. スクロースリン酸合成酵素 (SPS) 活性は幼果で高く，そ の後減少し，成熟果で再び上昇することはなかった。こ れは‘ラ・フランス’ 果実がへキソース蓄積型であって, スクロース蓄積型ではないためであるかもしれない。こ れらの結果から, NAD-SDH, SS そして S-AIV がセイヨ ウナシ果実の生長に必要な糖の供給，そして肥大のため のヘキソースへの変換に特に重要な役割を果たしている ことが示された. 